\title{
Perancangan ComuLife Aplikasi Pendukung Kebutuhan Masyarakat Menghadapi Pandemi Covid-19
}

\author{
Fidi Wincoko Putro, Leonard Julian Augusta Manoppo, Harya Abimanyu Athalla Akbar, \\ Ahmad Yuridan Zindani \\ Rekayasa Perangkat Lunak, Fakultas Teknologi Informasi dan Industri, Institut Teknologi Telkom Surabaya, \\ J1. Ketintang No.156, Kota Surabaya, Jawa Timur 60231, Indonesia \\ fidiwputro@ittelkom-sby.ac.id
}

\begin{abstract}
Abstrak
Pandemi Covid-19 saat ini melanda beberapa negara. Indonesia termasuk negara yang terkena dampak dari Covid-19 tersebut. Akibat dampak tersebut, tidak sedikit dari warga Indonesia yang terpapar virus tersebut. Hingga akhirnya pemerintah mengeluarkan kebijakan New Normal dimana masyarakat tetap dapat beraktivitas seperti biasa dengan menerapkan protokol kesehatan demi menjalankan roda perekonomian di Indonesia. Tetapi penyebaran Covid-19 terus bertambah hingga korban jiwa terus meningkat. Warga yang terpapar pun diharuskan melakukan isolasi mandiri selama 14 hari di rumah bersama keluarga mereka. Karena melakukan isolasi mandiri, maka warga yang terkonfirmasi positif Covid-19 kesulitan untuk memenuhi kebutuhan hidup sehari-hari. Sebenarnya masyarakat telah berusaha untuk saling membantu warga yang terkena Covid-19 untuk bertahan hidup selama masa isolasi, tetapi mereka takut terjadi kontak langsung. Oleh karena itu, penelitian ini mengusulkan rancangan suatu alat bantu berupa aplikasi ComuLife yang berfungsi sebagai alat komunikasi dan kolaborasi untuk membantu warga terkonfirmasi Covid-19 agar mampu bertahan hidup secara gotongroyong bersama masyarakat sekitar. Berdasarkan hasil penelitian, sekitar 61,1\% masyarakat menyatakan aplikasi tersebut sangat layak untuk digunakan.
\end{abstract}

Kata kunci: Covid-19, isolasi, aplikasi, bertahan hidup, masyarakat

\section{Pendahuluan}

Tahun 2020 ini seluruh negara sedang menghadapi sebuah bencana virus. Virus ini telah memakan korban jiwa dan semakin hari terus meningkat. Virus tersebut adalah SARS-CoV-2 atau yang lebih dikenal dengan Covid-19. Berdasarkan penjelasan dari World Health Organization (WHO), Covid-19 adalah sebuah penyakit yang disebabkan oleh Virus SARS-CoV-2 yang baru-baru ini ditemukan. Penyebaran virus yang begitu cepat tersebut disebabkan tetesan air liur atau cairan dari hidung saat bersin atau batuk dari orang yang terinfeksi. Kebanyakan orang yang terinfeksi Covid-19 akan mengalami gangguan pernafasan ringan hingga sedang tiada henti bahkan tidak kunjung sembuh.

Berdasarkan data Satuan Tugas Penanganan Covid-19, jumlah terkonfirmasi di Indonesia mencapai 187,537 ribu dengan penambahan +3.269 kasus di bulan September 2020. Dari 34 provinsi di Indonesia,penambahan kasus tertinggi berada di provinsi DKI Jakarta dengan jumlah kasus 44.280, lalu Jawa Timur 35.005 kasus, dan Jawa Tengah dengan 14.860 kasus (Satgas Penanganan COVID-19, 2020). Dari penambahan kasus tersebut dapat disimpulkan bahwa penyebaran dari Covid- 19 sangat cepat.

Sejumlah negara telah menciptakan beberapa aplikasi yang bertujuan memutus penyebaran Covid19 serta menghimbau akan bahayanya virus tersebut. Termasuk Indonesia yang turut serta dalam pembuatan aplikasi untuk pencegahan Covid-19 yang membuat aplikasi 10 Rumah Aman dan PeduliLindungi. Aplikasi ini berbentuk komunitas pencegahan dan edukasi mengenai Covid-19 sehingga dapat digunakan oleh masyarakat dan pemerintah (Yusuf, 2020). Kemudian aplikasi PeduliLindungi adalah aplikasi yang dikembangkan untuk membantu instansi pemerintah terkait dalam melakukan pelacakan untuk menghentikan penyebaran Coronavirus Disease (COVID-19) 
(PeduliLindungi, 2020). yang mengandalkan partisipasi masyarakat untuk saling membagikan data lokasinya saat bepergian agar penelusuran riwayat kontak dengan penderita Covid-19 dapat dilakukan. Pemerintah Australia juga menciptakan aplikasi bernama COVIDsafe yang memungkinkan pejabat kesehatan mengakses informasi tentang interaksi seseorang jika tertular virus (Australian Government Department of Health, 2020). Pemerintah Singapura juga menciptakan aplikasi TraceTogether yang berguna melacak kontak yang terkena Covid-19 (Stevens and Haines, 2020).

Lalu Pemerintah Korea bekerja sama dengan Korea Centers for Disease Control and Prevention (KCDC) menciptakan sebuah sistem Covid-19 Smart Management System (SMS) yang berguna membantu pihak berwenang dalam menganalisis pergerakan pasien yang terkena dampak dan yang berada di karantina (Kim and Ashihara, 2020).

Penyebaran Covid-19 juga telah menyebar di kota permukiman warga bahkan telah menyebar di desa desa di seluruh Indonesia. Satu persatu desa di Indonesia menambah kasus terkonfirmasi Covid-19 di Indonesia. Penyebaran Covid ini dapat berdampak pada desa atau permukiman warga,terutama jika terdapat salah satu warga yang terkena. Warga yang terkena akan diisolasi mandiri selama 14 hari dirumah bersama keluarga mereka. Ketika melakukan isolasi mandiri, warga tersebut tidak dapat keluar melakukan aktivitas bahkan mencari makan dan bahan keperluan mereka selama 14 hari kedepan. Mereka harus menunggu bantuan yang tidak pasti datangnya. Warga yang ingin membantu pun harus berpikir dua kali apabila ingin memberi bantuan dikarenakan status dari warga tersebut. Hal itu dapat berdampak pada kondisi kebutuhan hidup sehari-hari dan psikologis warga tersebut karena merasa dikucilkan dan tidak ada yang peduli. Oleh karena itu, penelitian ini mengusulkan untuk membuat suatu aplikasi untuk komunitas dimana warga tetap dapat membantu agar warga terkena dapat bertahan selama menjalani isolasi di rumah.

Penelitian ini mengusulkan rancangan aplikasi bernama ComuLife apakah layak untuk diimplementasikan ke masyarakat. Aplikasi tersebut adalah aplikasi berbasis komunitas dimana kita dapat membentuk komunitas lalu membentuk ruang komunikasi dan kolaborasi dengan memasukkan nomor telepon seluler masyarakat. Warga tetap dapat membantu walau dari rumah sekalipun sehingga kebutuhan warga yang terkena Covid-19 dapat tercukupi selama 14 hari kedepan. Dengan ComuLife, diharapkan warga yang terkena Covid-19 dapat terbantu dalam kebutuhan sehari- hari serta kondisi mental warga tersebut dapat pulih.

\section{Metode Penelitian}

Seluruh tahapan metode penelitian disusun sesuai dengan diagram pada Gambar 1 di bawah ini.

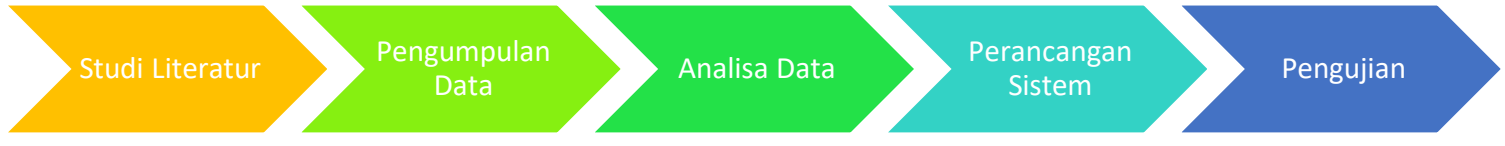

Gambar 1. Diagram metode penelitian

Dalam penelitian ini, digunakan beberapa metode penelitian, Metode penelitian tersebut diantaranya sebagai berikut:

1) Studi Literatur: dalam tahapan ini, dilakukan pencarian dan mempelajari beberapa referensi aplikasi yang menyerupai aplikasi yang diusulkan. Aplikasi yang serupa nantinya dapat menjadi acuan dalam penelitian ini sehingga dapat dikembangkan menjadi sebuah aplikasi.

2) Pengumpulan data: pada tahap pengumpulan data, dilakukan survey untuk mengetahui respon para masyarakat apakah mereka membutuhkan alat bantu untuk bertahan hidup menghadapi pandemi Covid-19.

3) Analisa data: setelah melakukan pengumpulan data, data yang telah dikumpulkan dari para responden akan dilakukan observasi dan analisa sehingga didapat hipotesis sementara. 
4) Perancangan Sistem: pada tahap perancangan sistem ini akan disusun alur sistem berupa flowchart yang akan menjadi acuan dalam pembuatan aplikasi. Pada tahap ini juga ditunjukkan tampilan rancangan aplikasi yang akan dibuat.

5) Pengujian: pada pengujian rancangan sistem, akan dilakukan survey kembali terhadap rancangan sistem aplikasi sehingga mendapat hasil akhir terhadap kelayakan atau penerimaan aplikasi di masyarakat.

\section{Hasil dan Pembahasan}

Pada pengembangan aplikasi ini, dilakukan pencarian beberapa referensi dari aplikasi sebelumnya yang berhubungan dengan Covid-19. Bebarapa referensi mengenai aplikasi tersebut yaitu sebuah aplikasi yang bernama 10 Rumah Aman. Aplikasi ini berbentuk komunitas pencegahan dan edukasi mengenai Covid-19 sehingga dapat digunakan oleh masyrakat dan pemerintah. Aplikasi ini berguna untuk memantau penyebaran Covid-19 di lingkungan rumah. Aplikasi ini juga dapat mengukur suhu tubuhnya sendiri, memeriksa kesehatan secara mandiri dan memantau daerah atau masyarakat mana yang memiliki potensi penyebaran Covid- 19, melalui pantauan suhu tubuh agar dapat menghindari daerah tersebut. Aplikasi ini lebih menuju arah edukasi mengenai Covid-19. Selain 10 Rumah Aman, Indonesia juga menciptakan aplikasi PeduliLindungi. PeduliLindungi adalah aplikasi yang mengandalkan partisipasi masyarakat untuk saling membagikan data lokasinya saat bepergian agar penelusuran riwayat kontak dengan penderita Covid-19 dapat dilakukan. Ketika saling berpapasan dengan sesama pengguna, maka akan terjadi pertukaran id secara anonim. PeduliLindungi juga akan memberi tahu pengguna jika pernah berpapasan dengan orang yang telah menjadi ODP atau OTG. Dapat disimpulkan bahwa PeduliLindungi lebih menuju aplikasi pelacakan dan penghimbau keramaian.

Sejumlah negara lain juga ikut menciptakan beberapa aplikasi guna memutus penyebaran Covid19. Pemerintah Australia juga menciptakan sebuah aplikasi bernama COVIDsafe. Aplikasi ini memungkinkan pejabat kesehatan mengakses informasi tentang interaksi seseorang jika tertular virus. Dapat disimpulkan aplikasi ini lebih kepada pemberian informasi kepada para pekerja di bidang kesehatan. Pemerintah Singapura juga menciptakan aplikasi bernama TraceTogether. Aplikasi ini berguna melacak sesama pengguna dalam radius 2 meter. Untuk menggunakannya pengguna harus selalu mengaktifkan bluetooth mereka agar pemerintah dapat melacak pengguna lain. Dapat disimpulkan bahwa TraceTogether juga menuju ke aplikasi pelacakan. Lalu Pemerintah Korea bekerja sama dengan Korea Centers for Disease Control and Prevention (KCDC) membuat sebuah sistem Covid-19 Smart Management System (SMS). Sistem ini berguna membantu pihak berwenang dalam menganalisis pergerakan pasien yang terkena dampak dan yang berada di karantina. Dapat disimpulkan aplikasi ini lebih ke arah pemantauan terhadap para pasien yang berada di karantina.

Dari beberapa referensi diatas dapat dijadikan dugaan sementara bahwa aplikasi yang diusulkan akan sangat dibutuhkan bagi para masyarakat. Karena mengingat belum terdapat aplikasi untuk membantu masyarakat positif Covid-19 memenuhi kebutuhan sehari harinya selama isolasi mandiri 14 hari.

Untuk mendukung pengembangan aplikasi ini, dilakukan pengumpulan data dengan melakukan survei menggunakan Google Form. Survei ini dilakukan pada tanggal 07 September 2020 yang bertujuan melihat respon dari para masyarakat yang nantinya berpotensi akan menggunakan pengembangan aplikasi ini. Survei dilakukan dengan memberikan 7 pertanyaan yang nantinya akan dijawab para responden pada Google Form yang telah dikirim. Target para responden adalah para mahasiswa serta masyarakat. Terhitung dari tanggal dibuatnya form yaitu 07-09 September 2020 telah mendapat 53 tanggapan dari para responden. Tanggapan tersebut telah disusun pada tabel di bawah ini. 
Tabel 1. Posisi selama pandemi Covid-19

\begin{tabular}{ccc}
\hline Pertanyaan & Kota & Desa \\
\hline Dimanakah posisi anda saat ini selama pandemi Covid-19? & $77.36 \%$ & $22.64 \%$ \\
\hline
\end{tabular}

Tabel 2. Tempat tinggal

\begin{tabular}{ccc}
\hline Pertanyaan & Ya & Tidak \\
\hline Apakah tempat tinggal anda termasuk permukiman warga? & $98.11 \%$ & $1.89 \%$ \\
\hline
\end{tabular}

Tabel 3. Warga atau tetangga dalam pemantauan

\begin{tabular}{ccc}
\hline Pertanyaan & Ya & Tidak \\
\hline $\begin{array}{c}\text { Apakah di tempat tinggal anda saat ini sudah terdapat warga atau tetangga } \\
\text { yang menjadi ODP(Orang Dalam Pemantauan)? }\end{array}$ & $49.06 \%$ & $50.94 \%$ \\
\hline
\end{tabular}

Tabel 4. Kebutuhan warga terpenuhi

\begin{tabular}{cccc}
\hline Pertanyaan & Ya & Tidak Tahu & Tidak \\
\hline $\begin{array}{c}\text { Selama warga tersebut menjalani isolasi mandiri,apakah } \\
\text { kebutuhan warga tersebut terpenuhi? }\end{array}$ & $62.26 \%$ & $15.09 \%$ & $22.64 \%$ \\
\hline
\end{tabular}

Tabel 5. Ikut membantu warga

\begin{tabular}{cccc}
\hline Pertanyaan & Ya & Tidak Tahu & Tidak \\
\hline Apakah anda ikut membantu warga tersebut? & $49.06 \%$ & $11.32 \%$ & $39.62 \%$ \\
\hline
\end{tabular}

Tabel 6. Jika terdapat aplikasi

\begin{tabular}{cccc}
\hline Pertanyaan & Mungkin & Tidak Tahu & Ya \\
\hline $\begin{array}{c}\text { Jika terdapat sebuah aplikasi atau inovasi guna meringankan } \\
\text { beban warga tersebut,bagaimana pendapat anda? }\end{array}$ & $32.08 \%$ & $1.89 \%$ & $66.04 \%$ \\
\hline
\end{tabular}

Setelah melakukan pengumpulan data, dapat ditarik dugaan ilmiah bahwa aplikasi untuk membantu masyarakat bertahan hidup dari pandemi Covid-19 sangat diperlukan. Oleh karena itu, dilakukan perancangan sistem yang digambarkan dalam bentuk flowchart seperti pada Gambar 2.

Setelah membuat perancangan sistem dalam bentuk flowchart, membuat desain aplikasi. Terdapat beberapa fitur-fitur pada aplikasi yang berguna mempermudah pada penggunaan aplikasi tersebut. Fitur fitur tersebut diantaranya:

a. Fitur Chats, fitur ini dapat digunakan untuk berbicara dengan para pengguna baik personal maupun membuat grup.

b. Fitur Donation, fitur ini dapat digunakan untuk mengumpulkan donasi bagi warga yang kebutuhan sehari harinya sangat sulit selama menjalankan isolasi mandiri.

c. Fitur Tasks, fitur ini digunakan ntuk membantu warga yang meminta bantuan dalam keadaan darurat yang diisi oleh warga positif Covid-19.

d. Fitur Needs, fitur ini ditujukan bagi pengguna yang memiliki status positif Covid-19. Fitur ini digunakan untuk meminta bantuan guna memenuhi kebutuhan sehari hari selama isolasi mandiri 14 hari.

e. Fitur Helper, fitur ini digunakan untuk memberi informasi terkait status orang yang membantu atau bantuan yang telah diberikan kepada keluarga positif Covid-19. 


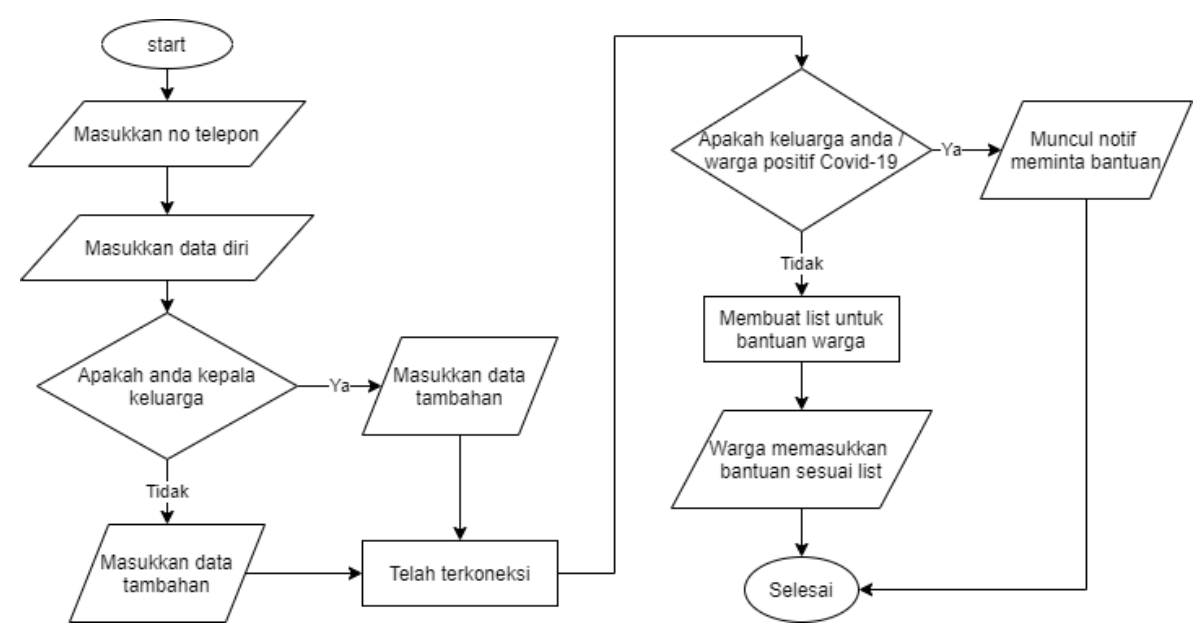

Gambar 2. Diagram alir sistem

Desain bagian antarmuka pengguna (User Interface) pada aplikasi ini dibuat sedemikian rupa agar pengguna yang dalam ini pasien dan warga masyarakat bisa secara mudah menggunakan aplikasi ini. Gambar 3 adalah desain $U I$ aplikasi yang disusun sesuai dengan alur aplikasi.

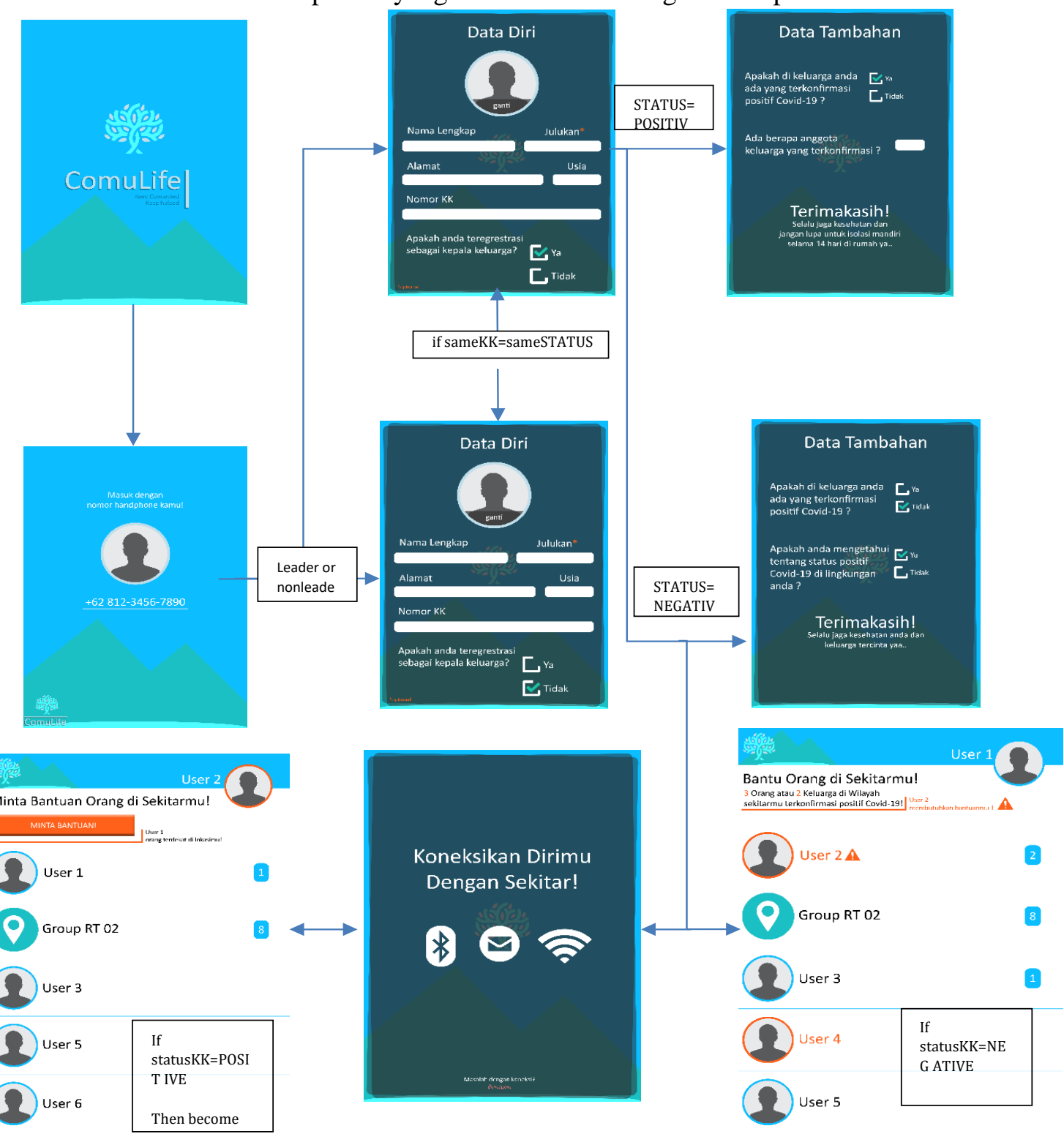

Gambar 3. Desain User Interface 
Setelah melakukan pembuatan mockup aplikasi melalui flowchart, dilakukan survey akhir. Survey akhir ini dilakukan untuk melihat pendapat masyarakat mengenai tampilan dan fitur fitur pada aplikasi tersebut. Survey tersebut dilakukan dengan membuat video penggunaan aplikasi tersebut kemudian hasilnya telah disusun dalam diagaram seperti gambar di bawah.

Setelah menonton video tersebut, bagaimana pendapat kalian mengenai tampilan aplikasi

tersebut?

36 responses

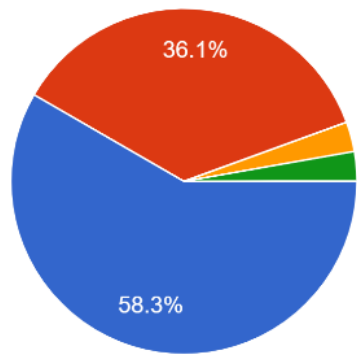

Gambar 4. Survey tampilan aplikasi

Pada Gambar 4 menunjukkan pertanyaan pertama bagaimana pendapat kalian mengenai tampilan aplikasi tersebut, 58,3 persen menjawab sangat bagus, 36,1 persen menjawab cukup bagus dan sisanya menjawab kurang bagus. Dari presentase diagram diatas, dapat disimpulkan bahwa desain dari aplikasi ComuLife disukai para masyarakat.

Setelah menonton video tersebut, bagaimana pendapat kalian mengenai fitur-fitur pada aplikasi tersebut?

36 responses

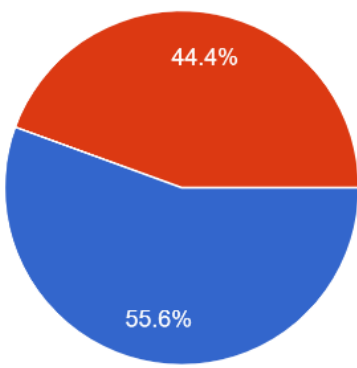

Gambar 5. Survey fitur aplikasi

Pada Gambar 5, menunjukkan pertanyaan kedua bagaimana pendapat kalian mengenai fitur fitur aplikasi tersebut, 55,6 persen menjawab sangat mudah digunakan, 44,4 persen menjawab cukup mudah digunakan. Dari presentase diagram diatas, dapat disimpulkan bahwa fitur pada aplikasi ComuLife mudah digunakan bagi para masyarakat. 
Setelah menonton video tersebut, apakah aplikasi tersebut layak dipakai masyarakat terdampak

Covid-19?

36 responses

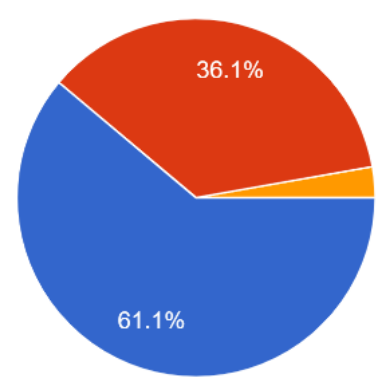

Sangat Layak

Cukup Layak

Kurang Layak

Tidak Layak

Gambar 6. Survey kelayakan aplikasi

Pada Gambar 6, menunjukkan pertanyaan ketiga apakah aplikasi tersebut layak digunakan, 61,1 persen menjawab sangat layak, 36,1 persen menjawab cukup layak dan sisanya menjawab kurang layak. Dari presentase diatas, dapat disimpulkan bahwa aplikasi ComuLife layak digunakan bagi para masyarakat.

\section{Kesimpulan}

Setelah melewati beberapa proses dalam melakukan penelitian ini, berdasarkan hasil hasil dan pembahasan yang telah diuraikan diatas dapat diambil kesimpulan bahwa Aplikasi ComuLife yang diusulkan layak diimplentasikan dan digunakan oleh masyarakat. Dengan diimplementasikannya Aplikasi ComuLife, diharapkan aplikasi ini dapat membantu serta meringankan warga menghadapi pandemi Covid-19.

\section{Ucapan Terima Kasih}

Pada akhir halaman ini, saya beserta anggota tim penelitian mengucapkan terima kasih yang sebesar besarnya seluruh civitas akademika Institut Teknologi Telkom Surabaya yang membantu dalam penelitian maupun penulisan artikel. Ke depan diharapkan agar penelitian ini dapat memberikan ide-ide yang lebih kreatif dan inovatif serta dapat mengimplementasikannya.

\section{Daftar Pustaka}

Australian Government Department of Health (2020) 'COVIDSafe app | Australian Government Department of Health', Health.Gov.Au. Available at: https://www.health.gov.au/resources/appsand-tools/covidsafe-app (Accessed: 23 October 2020).

Kim, J. and Ashihara, K. (2020) 'National disaster management system: COVID-19 case in Korea', International Journal of Environmental Research and Public Health, 17(18), pp. 1-18. doi: 10.3390/ijerph17186691.

PeduliLindungi (2020). Available at: https://pedulilindungi.id/ (Accessed: 23 October 2020).

Satgas Penanganan COVID-19 (2020) Peta Sebaran| Satgas Penanganan COVID-19, Satgas Penanganan COVID-19. Available at: https://covid19.go.id/peta-sebaran (Accessed: 10 September 2020).

Stevens, H. and Haines, M. B. (2020) TraceTogether: Pandemic response, democracy, and technology, read.dukeupress.edu. Available at: https://read.dukeupress.edu/easts/articleabstract/14/3/523/166339 (Accessed: 23 October 2020).

Yusuf (2020) Aplikasi 10 Rumah Aman, Upaya Pemerintah Tangkal Covid-19, 30/4/2020. Available at: https://aptika.kominfo.go.id/2020/04/aplikasi-10-rumah-aman-upaya-pemerintah-tangkal-covid19/ (Accessed: 23 October 2020). 